PSICOLOGÍA

IBEROAMERICANA
Psicología Iberoamericana ISSN: 1405-0943

revista.psicologia@ibero.mx

Universidad Iberoamericana, Ciudad de México México

\title{
Scientific publishing and social responsibility
}

Turnbull, Bernardo

Scientific publishing and social responsibility

Psicología Iberoamericana, vol. 27, núm. 2, 2019

Universidad lberoamericana, Ciudad de México, México

Disponible en: http://www.redalyc.org/articulo.oa?id=133962309007 


\title{
Scientific publishing and social responsibility
}

\author{
Bernardo Turnbull bernardo.turnbull@ibero.mx \\ Universidad Iberoamericana, Ciudad de México, México \\ http://orcid.org/0000-0001-9663-913X
}

Psicología Iberoamericana, vol. 27, núm. 2,2019

Universidad Iberoamericana, Ciudad de México, México

Redalyc: http://www.redalyc.org/ articulo.oa?id=133962309007
Scientific publishing and social responsibility are part of the identity and the mission of our university, especially in the field of psychology.

The psychology department, for quite a few years now, has embraced the concept of social responsibility by embedding it in the academic and interpersonal training of our students. Our pre-professional practicum programme has become the backbone of our study plan. In this practicum, the students directly help those who cannot afford mental health services. This adds a new dimension to the profession because it helps the students connect with their community and the critical social problems affecting Mexico. It confirms the commitment that every professional should make to their community and country. Thus, besides giving direct aid to the community, students can gain the skills and attitudes necessary to exercise a socially responsible professional life.

However, psychology is a scientific discipline and we must incorporate social responsibility into how we construct knowledge in the field of psychology. Our scientific journal, Psicología Iberoamericana is also committed to the university's goal of fostering social responsibility. A scientific journal could detach itself from such a mission, however we believe that acknowledging social responsibility and the realities of the socio-economic challenges facing Mexico is vital to the creation of valid scientific knowledge in the field of psychology. In this way, we build a science that serves not only science itself, but mainly the wider community.

Even when research reports the outcome of psychological interventions, this can be interesting but useless if there are no practical implications of the research or acknowledgement of the wider socioeconomic challenges and power relations at work. The help given to the privileged enable professionals to make money, but this alone does not create knowledge that helps the majority. We should seek psychological intervention that departs from critical consciousness and, at the same time, strengthen it. The scientific report of this type of research retrieves the humanistic meaning of psychology and at the same time it also places useful knowledge at the service of the legitimate owners of the data: the people who gave us the information to do research and publish. 
Psicologia Iberoamericana seeks to walk this road along with our professors and students. We wish to spread the knowledge created by our academics and professionals. This knowledge must be part of our student's training from the bachelor to the postgraduate level. It is also necessary to tap into the experiences of the pre-professional practicum programme in scientific publications that take advantage of this knowledge and spread it for purposes of serving the community. Our library holds doctoral dissertations and books that focus on this process and all of this should contribute to building our students' social commitment and refining their skills to bring this into action. The exchange of research findings and making them available to other professionals is mutually beneficial as well.

If our department is trying to put students in touch with the reality of the social problems affecting the majority of the population in Mexico to build a sense of social responsibility, then our journal seeks to bring students and knowledge creation together to close the learning circle. 